\title{
Retreatment and maintenance therapy with infliximab in fistulizing Crohn's disease
}

\author{
L. Rodrigo, J. M. Pérez-Pariente, D. Fuentes, V. Cadahia, A. García-Carbonero, P. Niño, R. de Francisco, R. Tojo, \\ M. Moreno and E. González-Ballina
}

Service of Digestive Diseases. Hospital Central de Asturias. Oviedo. Spain

\begin{abstract}
Objectives: infliximab has clearly demonstrated its efficacy in the short-term treatment of fistulizing Crohn's disease. We present here the results of retreatment and long-term maintenance therapy.

Patients and methods: eighty one consecutive patients with active fistulizing Crohn's disease, in whom previous treatments had failed, were treated with infliximab. All patients received as the initial treatment of $5 \mathrm{mg} / \mathrm{kg}$ i.v. infusions (weeks 0,2 , and 6). Those patients who failed to respond after the initial cycle (group $1, \mathrm{n}=25$ ), or those who relapsed after having responded (group $2, n=13$ ), received retreatment with three similar doses (weeks 0,2 , and 6). Those who responded to retreatment were included in a long-term maintenance programme $(n=44)$, with repeated doses ( $5 \mathrm{mg} / \mathrm{kg}$ i.v. infusions) every eight weeks for $1-2$ years.

Results: in the initial treatment $56 \%$ of the patients responded partially; this response being complete in $44 \%$. In the retreatment, $28 \%$ of group 1 (non-responders) presented a complete response, compared to $77 \%$ in group 2 (relapsers) ( $p<0.0001$ ). In the maintenance treatment, the global response was $88 \%$ (39/44). The mean number of doses per patient was $4.4 \pm 2$ (range 1-9) with a duration of $36 \pm 12$ weeks (range 8-72). Adverse effects were not significantly increased in either treatment.

Conclusions: both retreatment and long-term maintenance therapy with infliximab, are highly effective and well tolerated in fistulizing Crohn's disease patients.
\end{abstract}

Key words: Retreatment. Maintenance therapy. Infliximab. Fistulizing Crohn's disease.

Rodrigo L, Pérez-Pariente JM, Fuentes D, Cadahia V, GarcíaCarbonero A, Niño $P$, de Francisco $R$, Tojo $R$, Moreno $M$, González-Ballina E. Retreatment and maintenance therapy with infliximab in fistulizing Crohn's disease. Rev Esp Enferm Dig 2004; 96: 548-558.

Recibido: 13-11-03

Aceptado: 27-01-04.

Correspondencia: Luis Rodrigo. Servicio de Aparato Digestivo. Hospital Central de Asturias. C/ Celestino Villamil, s/n. 33006 Oviedo. e-mail: lrodrigos@terra.es

\section{INTRODUCTION}

Crohn's disease (CD) causes inflammation of the full thickness of the bowel wall and may involve any part of the gastrointestinal tract.

This disease may present various local complications including the presence of fistulas, both internal (entero-enteric, entero-vesical, etc.) and external (perianal, entero-cutaneous, etc.).

Various medical treatments have been employed for the management of $\mathrm{CD}$, amongst which are corticosteroids, aminosalicylates, antibiotics and immunosuppressants, alone or in combination.

Various investigators have shown that the production of TNF $\alpha$ is increased both in the serum and in intestinal mucosa of patients with CD $(1,2)$. Infliximab (Remicade $^{\circledast}$ ) is a human-murine chimeric monoclonal antibody, which is capable of joining the soluble and transmembrane forms of TNF $\alpha$, blocking their interaction with receptors, neutralizing its biological activity $(3,4)$, and inducing a local immunomodulatory and anti-inflammatory action (5-7).

Several studies have demonstrated the efficacy of infliximab in the treatment of $\mathrm{CD}$, both in inflammatory forms (8) and in cases with associated fistulas (9).

Although its efficacy in the short-term control of fistulous disease has been well demonstrated, in the mediumterm (around 12 weeks), a considerable number of patients present with relapses. Several investigators have attempted to find factors related to individual variability in response and its duration (10-14). Up to the present it has not been possible to identify clinically useful predictors.

The approach to follow in medium-term treatment is a subject open to debate, on which there is little experience for the time being.

The aim of this study is to describe our experience in the treatment of fistulizing $\mathrm{CD}$ with infliximab in the long-term, including retreatment and maintenance therapy. 


\section{PATIENTS AND METHODS}

From April 1999 to the present day, a total of 81 consecutive patients with fistulizing $\mathrm{CD}$ have been treated with infliximab. A diagnosis of $\mathrm{CD}$ was confirmed by means of clinical, endoscopic, radiological and histological criteria according to Lennard-Jones (15).

Patients were informed of the state of their disease and of the different therapeutic possibilities, and at the same time they received detailed information about the characteristics of infliximab and its adverse effects; a written informed consent was obtained. Prior to the intravenous infusion, a tuberculin test and chest radiograph, were obtained for all patients. The protocol and treatment regimen were approved by the Ethics Committee of our hospital.

The indication established for the treatment in our series was the presence of fistulizing $\mathrm{CD}$, with active drainage for at least three months, prior to the infusion of infliximab, in spite of the use of previous treatments with different drugs (aminosalicylates, antibiotics, immunosuppressants, etc.), and patients were included consecutively on attending our department (both inpatients and outpatients).

For the evaluation of fistulous disease, a physical examination of the perianal region was performed, together with total colonoscopy, endoanal sonography and magnetic resonance of the pelvis, in order to assess the number, site and activity of fistulas.

Eighty-nine percent of patients had been previously treated with a standard dose of azathioprine $(2.5 \mathrm{mg} / \mathrm{kg}$ /day for $28 \pm 26$ months, range 6-120).

Infliximab was intravenously infused, at a dose of $5 \mathrm{mg} / \mathrm{kg}$ for two and a half hours, following the manufacturer's instructions (Schering-Plough Laboratories, USA), in three doses separated by usual intervals (weeks 0,2 and 6). Our day hospital was used for this purpose.

Patients remained there for 6 hours, during which time vital signs were controlled. All patients were clinically observed every 15-30 minutes for the possible appearance of adverse effects, both during the intravenous infusion and during the 3 following hours. Patients were then discharged and followed-up by phone, every 24 hours for 3 days.

Any clinical event which occurred during the intravenous infusion, observation period, and later follow-up, was recorded. Periodic checkups were made at weeks 2 and 4 after the intravenous infusion, and later every 4 weeks or when the patient experienced any complication or clinical change in the disease, and when she/he attended our department.

Physical examination, blood count and biochemical analysis including acute phase reagents were obtained in each visit, and alterations in the course of the disease, such as the appearance of flare-ups, changes in the number and activity of fistulas, and/or development of other possible complications related to the disease (abscesses, suboclusive episodes, etc.) were recorded in detail.

In cases where doubts existed regarding the closure of fistulous tracts, the opening of new ones, or the possibility of new complications related to the abovementioned events, imaging studies (endoanal sonography and/or pelvic magnetic resonance) were repeated.
For the evaluation of results, response was considered as the closure of at least $50 \%$ of the fistulas existing at the beginning of treatment, and complete response was the closure of all fistulas.

From February 2000 retreatment was begun by administering three new doses in an attempt to obtain a response in those patients who had not achieved a response to initial treatment (group 1, $\mathrm{n}=25$ ) and in those who had responded and later relapsed (group 2, n =13). Eleven patients refused retreatment for the following reasons: refusal due to lack of efficacy $(n=6)$ or submission to surgery $(n=5)$.

From March 2001 a maintenance program was begun for those patients who had responded (both after the initial cycle and after retreatment). In this case, a single i.v. infusion of $5 \mathrm{mg} / \mathrm{kg}$ was administered every 8 weeks. This included a total of 44 patients, of whom 19 had previously undergone retreatment, while 25 had entered directly from initial treatment (Fig. 1).

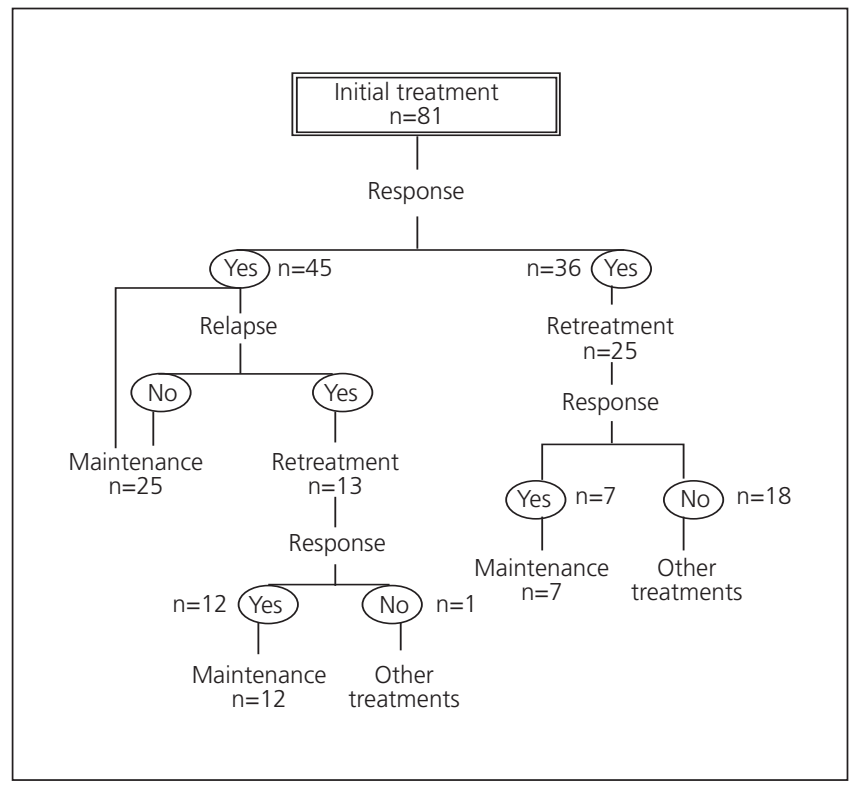

Fig. 1.-Algorithm for treatment modalities used during the study period, with the number of patients included in each group in relation with type of response.

Algoritmo de los tratamientos realizados por los pacientes durante el período del estudio con el número de pacientes incluidos en cada grupo en relación con el tipo de tratamiento empleado.

No control group was available, as we included all responding patients in this program. We did not administer premedication with corticosteroids and/or anti-histaminics prior to the i.v. infusion of new doses of infliximab.

\section{Statistical analysis}

Quantitative variables are expressed as mean \pm standard deviation, and qualitative variables as percentages. For the analysis of the results obtained Student's t test was used for 
quantitative data and the Chi square test with Fisher's correction for qualitative data and percentages. Data not following a homogeneous distribution were analysed using non-parametric techniques (Mann-Whitney U and KruskalWallis). For the analysis of the different demographic factors a multivariate analysis was performed. A p $\leq 0.05$ was considered statistically significant. The statistical package SPSS, version 11.0 (SPSS. Inc) was employed for the analysis of data.

\section{RESULTS}

Patients were grouped in accordance with the classification of Vienna. The site of the majority of fistulas was perianal $(80 \%)$. Other variables such as gender, toxic habits and duration of disease and fistulas were collected and are shown (Table I).

Table I. Baseline characteristics of patients $(n=81)$

$\begin{array}{lc}\text { Age (years) (mean } \pm \text { SD, range) } & 36 \pm 14(18-72) \\ \text { Gender (females/ males) (n, relation) } & 37 / 44(1 / 1.2) \\ \text { Duration of disease (years) (mean, range) } & 7.6 \pm 7(1-25) \\ \text { Duration of fistulas (years) (mean, range) } & 2.3 \pm 2.4(1-10) \\ \text { Smokers (n, \%) } & 27(33 \%) \\ \quad \text { Yes } & 43(53 \%) \\ \quad \text { No } & 11(14 \%) \\ \quad \text { Ex-smokers } & \\ \text { Site of disease [n (\%)] } & 24(30 \%) \\ \quad \text { leocecal (L1) } & 11(13 \%) \\ \text { Colonic (L2) } & 46(57 \%) \\ \quad \text { leocolonic (L3) } & \\ \text { Azathioprine [n (\%)] } & 73(89 \%) \\ \quad \text { Yes } & 8(11 \%) \\ \text { No } & \\ \text { Site of fistulas [n (\%)] } & 65(80 \%) \\ \quad \text { Perianal } & 13(16 \%) \\ \text { Enterocutaneous } & 3(4 \%) \\ \text { Both } & 2 \pm 1.2(1-6) \\ \text { Number of fistulas (mean, range) } & \end{array}$

\section{Results of the initial treatment}

A response was achieved in $55.6 \%$ of patients (45/81) in week $2.1 \pm 1$. Response was complete in $44.4 \%$ of cases $(36 / 81)$, this being reached in week $2.5 \pm 1$.

None of the 4 patients with associated enterovesical fistulas and only one of the 4 patients with enterovaginal fistulas presented closure. On analysing the characteristics of responders compared to non-responders no significant differences were found.

The duration of the disease approached significance $(\mathrm{p}=$ $0.05)$, this being longer for non-responders $(9.6 \pm 7.6$ vs 6.3 \pm 6 years) (Table II).

\section{Retreatments}

Group $1(n=25)$ : a response was only found in $28 \%$ $(7 / 25)$ in week $2.4 \pm 1.2$. Response was complete in all of these. Of these patients, 3 corresponded to cases in which azathioprine was administered after the infusion of the first infliximab course. No statistically significant differences were observed between responders and non-responders. $\mathrm{Re}$ sponders were later included in the maintenance program.

Group $2(n=13)$ : response was achieved in $92.3 \%$ of cases (12/13), and complete response in $77 \%$ (10/13). Responders were similarly included in the maintenance program.

On comparing the percentage of responses between groups 1 and 2, statistically significant differences were observed ( $\mathrm{p}<0.0001)$ (Fig. 2).

\section{Maintenance therapy}

Out of a total of 44 patients treated only 5 relapsed. The maintenance index to the initial response was $88 \%(39 / 44)$, with a mean number of doses of $4.4 \pm 2$ per patient (range 1 9) (Fig. 3), which is equivalent to $36 \pm 12$ weeks $(8-72$ weeks). Week 0 for maintenance treatment was considered the beginning of the new treatment (Fig. 4).

Table II. Responders vs non-responders

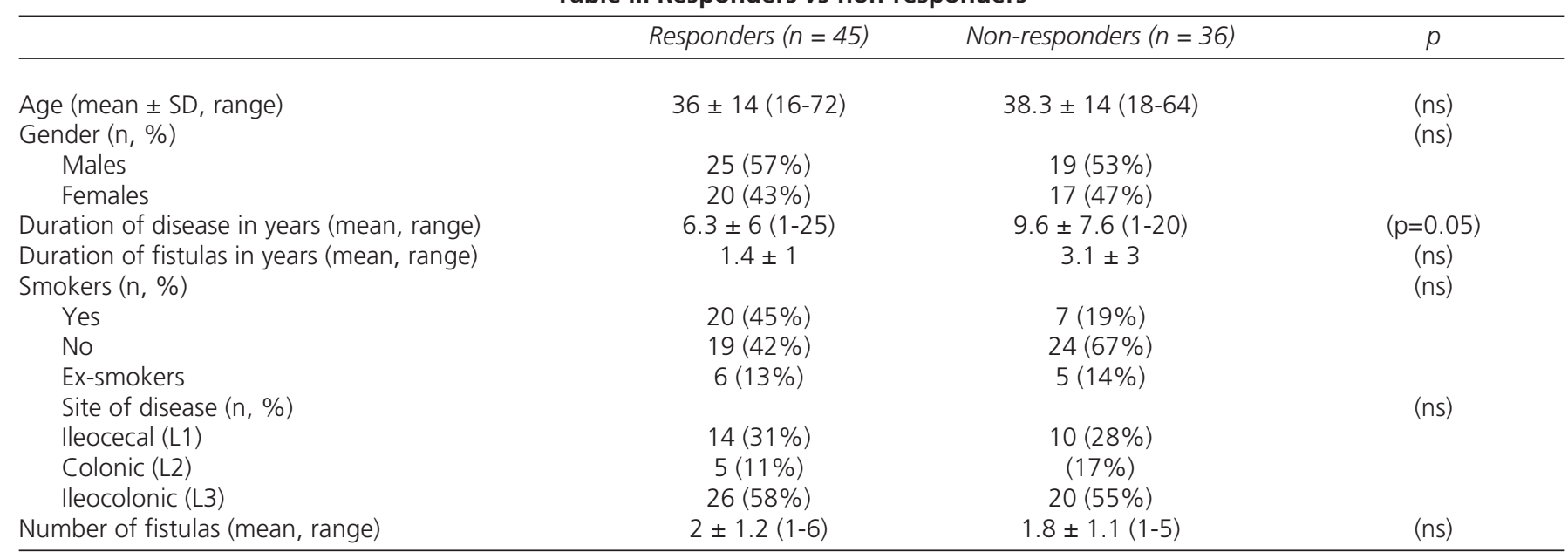




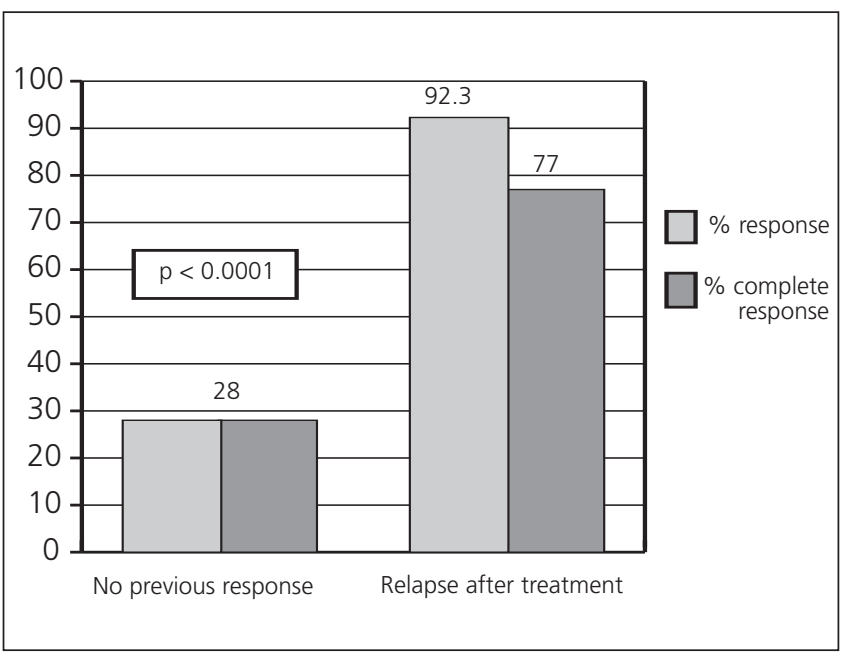

Fig. 2.- Retreatment with infliximab, comparing the efficacy between patients who did not respond to initial treatment (group 1) and those who had their fistulas healed after the first treatment and later relapsed (group 2).

Gráfica que compara los porcentajes de respuesta entre los pacientes que no habían respondido al tratamiento previo (grupo 1) y los que sufrieron recidiva (grupo 2).

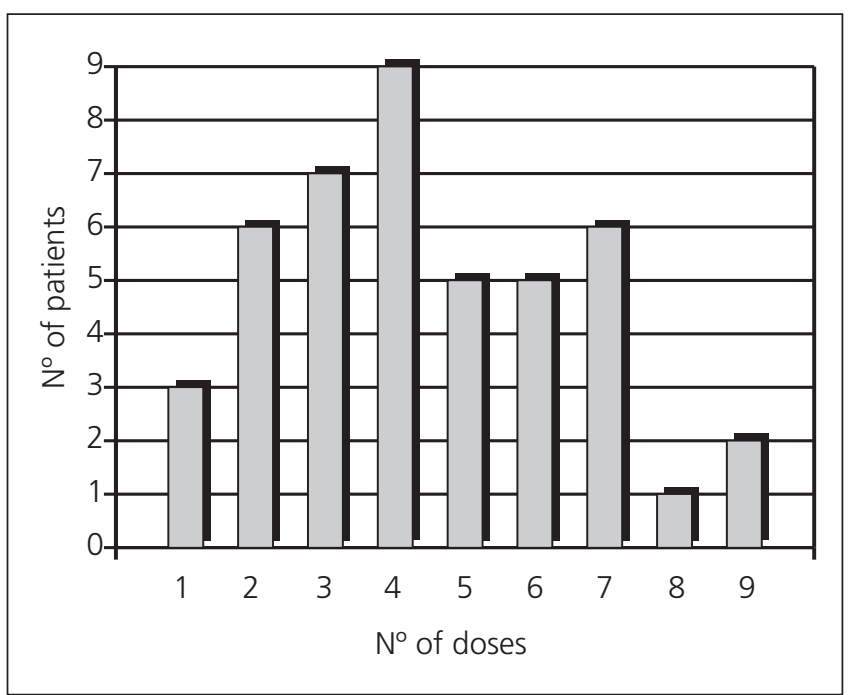

Fig. 3.- Long-term maintenance treatment with IFX. Number of patients grouped according to number of doses received.

Tratamiento de mantenimiento con infliximab. Número de pacientes agrupados de acuerdo con el número de dosis recibidas.

\section{Adverse effects}

The main adverse effects observed are shown in figure 5. Three cases of pulmonary tuberculosis were observed. The tuberculin test and chest X-ray prior to treatment had been negative; two cases appeared after initial treatment and one after retreatment, all of which were completely cured after specific treatment. The i.v. infusion was stopped in two patients - in one due to subjective dyspnea, and in the other

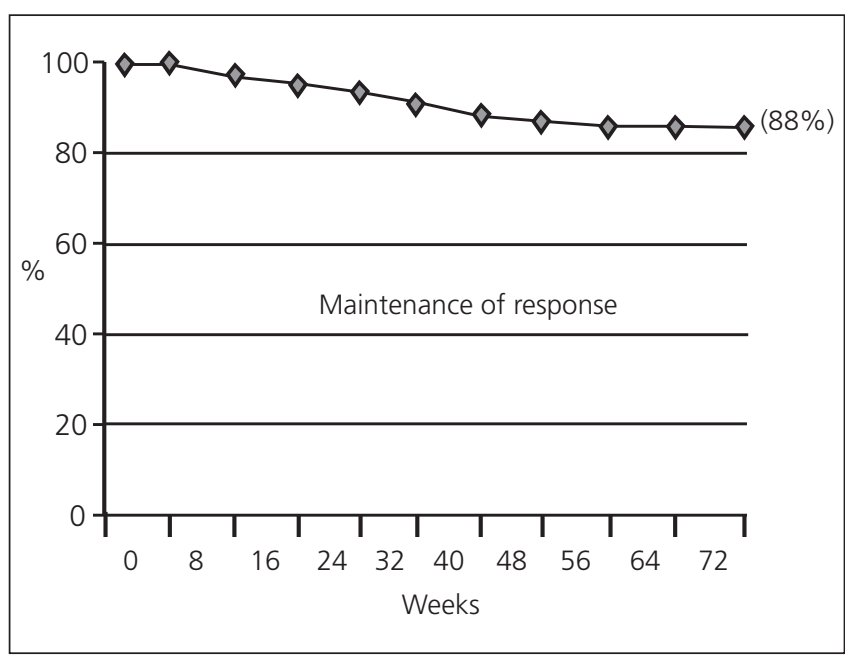

Fig. 4.- Long-term maintenance treatment with IFX. Percentage of patients who presented a complete response along the treatment period. Tratamiento de mantenimiento con infliximab. Porcentaje de pacientes que presentaron respuesta completa durante el periodo de tratamiento de mantenimiento.

one, due to an anaphylactic reaction, which was controlled satisfactorily with standard medical treatment (antihistaminics and corticosteroids). The latter case was a patient who underwent a second dose of retreatment, 7 months after the first cycle.

In our series we did not observe a significant increase in the usual complications with the administration of retreatment or maintenance therapy.

During maintenance treatment we observed intermittent development of antinuclear antibodies (ANA) in 11 of 45 patients $(25 \%)$, none of whom presented a "lupus-like" reaction.

\section{DISCUSSION}

Treatment with infliximab has demonstrated its efficacy in the management of patients with $\mathrm{CD}$, both in controlled and in placebo studies (16), and in daily practice since commercialization. A number of questions initially raised have been partially answered, although some, whose answer has not been conclusively established, especially those concerning long-term management with this type of medication, remain unsolved.

The efficacy of infliximab in the closure of fistulas in CD has also been compared to placebo (17), and has clearly shown its superiority in controlled studies, including those using immunosuppressants $(18,19)$.

On analyzing the results obtained with the first cycle of treatment we observed a response rate of 55.6\%. These results are slightly smaller than those published in series such as those from the Mayo Clinic (20) (69\%), or those obtained by Farrel et al. (21) (65\%), and similar to other series (22).

The percentage of patients who presented a complete response $(44.4 \%)$ was also similar to the above-mentioned series, and greater than those obtained by Cohen et al. (23) (24\% at 


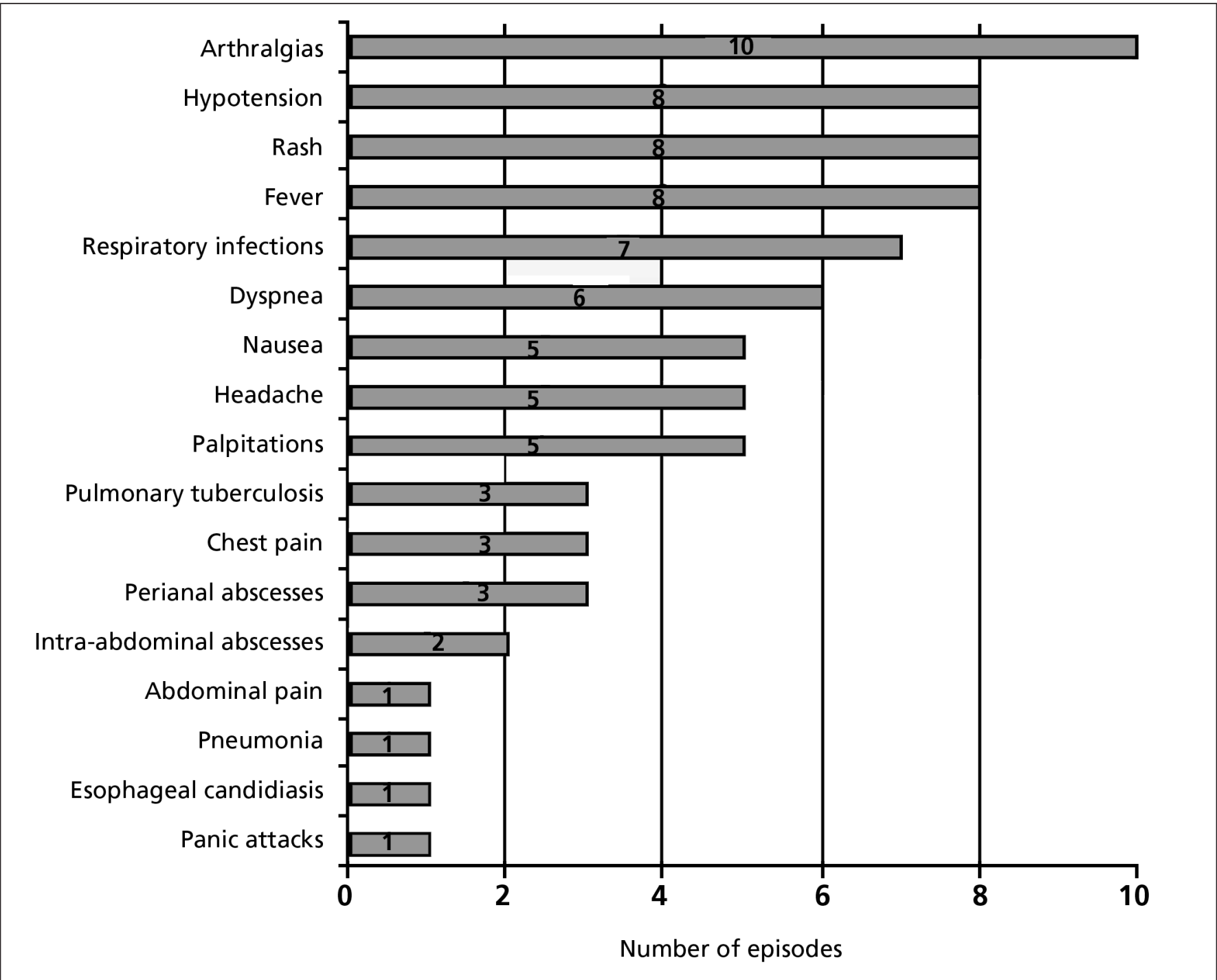

Fig. 5.- Type and frequency of side effects developed during maintenance treatment.

Tipo y frecuencia de los efectos secundarios aparecidos durante el tratamiento de mantenimiento.

week 3), this being probably due to the fact that in this series only $38 \%$ of patients received three complete doses.

With respect to the clinical and laboratory characteristics of patients, no significant differences were seen for the majority of these factors, between responders and non-responders, which is in agreement with other studies $(24,25)$. The duration of disease approached significance, probably due to the small size of the sample. This, in our series, is slightly greater among non-responders $(\mathrm{p}=0.05)$.

In a recent publication (26) a greater response rate has been reported for younger patients with chronic involvement and concomitant use of immunosuppressants. Other studies, however, have suggested a possible greater duration of response in non-smokers, although no differences were found in the percentage of initial response (27).

Several studies report a greater percentage of response in patients previously treated with azathioprine. In the retreatment phase we observed a lower percentage of response in group $1(28 \%)$, which supports the idea of "giving a second opportunity to these patients", although it is important to emphasize that 3 of these 7 responding patients corresponded to those who did not receive immunosupressive treatment during the first cycle, and it is possible that this percentage could be greater than that observed had azathioprine been employed (28).

In group 2, we obtained a higher percentage of responses $(92.3 \%)$, which was significantly greater to that achieved in group 1 . We therefore think that retreatment of a patient previously treated with infliximab who experienced closure and later reopening of fistulas (as usually occurs in the majority of cases in which only the initial cycle is administered) has a high possibility of achieving a new closure. 
Since the mean duration of response in patients with fistulas is around 12 weeks after initial treatment (17) we studied the effect of the i.v. infusion of repeated doses on the maintenance of response. Recent studies exist which show its efficacy, especially in the case of active inflammatory disease (29), such as ACCENT-1, a multicenter study with 573 patients (30), whose results show that maintenance treatment with infliximab in the inflammatory form of the disease, is highly effective, safe and well tolerated. Other previously published clinical series report the possibility that these results can also be obtained in fistulizing CD (20).

In our study, we confirmed this hypothesis, since the majority of patients who achieved an initial response, and who were included in the maintenance program, presented a prolonged closure of fistulas $(88 \%)$.

With respect to the safety of the medication, our findings are in accordance with results obtained elsewhere -in controlled clinical trials, other clinical series and reviews (31)and we did not observe a significant increase in adverse reactions with the administration of successive new doses.

One patient presented a moderate anaphylactic reaction, which was controlled satisfactorily with standard medical treatment. This patient was a 20 -year-old female, who had received a previous cycle of three doses with complete response and later relapse, for which reason it was decided to give another cycle, 7 months after the initial one; she presented this reaction after the first dose of the second cycle. In order to decrease this risk, we recommend restricting the time between cycles, since a prolonged period between doses appears to increase the percentage of such reactions (32).

Regarding the development of infections, the significant number of cases of tuberculosis described in the literature in relation to this medication (33) makes it necessary to bear in mind the possibility of such complication during treatment, especially in countries with a high prevalence of tuberculosis.

Other significant infectious complications were the development of three perianal abcesses and two abdominal ones, probably due to the fact that all patients presented active fistulas. We performed a systematic drainage of all possible perianal abscesses, prior to beginning treatment with infliximab, and provided antibiotics in all cases where it was necessary. Other adverse effects included community pneumonia and esophageal candidiasis, probably due to the use of concomitant immunomodulatory drugs (as several authors suggest) rather than to infliximab, despite the fact that several studies show a greater frequency of infections with infliximab alone (34).

We did not observe any tumors or lymphoproliferative disorders. Although similar to other studies (35) a percentage of patients exhibited ANA positivization during treatment with repeated doses, but no related complications were seen (lupus, lupus-like or collagenosis).

Finally, we wish to emphasize the medium- to longterm efficacy of retreatment and maintenance therapy in fistulizing CD, although future studies and longer followups will be necessary in order to draw more definitive conclusions.

\section{ACKNOWLEDGMENTS}

We wish to thank David H. Wallace (Member of the European Association of Science Editors) for the English language translation of the manuscript.

\section{REFERENCES}

1. Reimund JM, Wittersheim C, Dumont S, et al. Mucosal inflammatory cytokine production by intestinal biopsies in patients with ulcerative colitis and Crohn's disease. J Clin Immunol 1996; 16: 144-50.

2. Breese EJ, Michie CA, Nicholls SW, et al. Tumor necrosis factor alpha-producing cells in the intestinal mucosa of children with inflammatory bowel disease. Gastroenterology 1994; 106: 1455-66.

3. Scallon BJ, Moore MA, Trinh H, et al. Chimeric anti-TNF-alpha monoclonal antibody cA2 binds recombinant transmembrane TNF-alpha and activates immune effector functions. Cytokine 1995; 7: 251-9.

4. Siegel SA, Shealy DJ, Nakada MT, et al. The mouse/human chimeric monoclonal antibody cA2 monoclonal antibody cA2 neutralizes TNF in vitro and protects transgenic mice from cachexia and TNF lethality in vivo. Cytokine 1995; 7: 15-25.

5. Cornillie F, Shealy D, D'Haens G, et al. Infliximab induces potent anti-inflammatory and local immunimodulatory activity but not systemic immune suppression in patients with Crohn's disease. Aliment Pharmacol Ther 2001; 15: 463-73.

6. Ten Hove T, Van Montfrans C, Peppelenbosch M, et al. Infliximab treatment induces apoptosis of activated lamina propria T-lymphocytes in Crohn's disease. Gut 2002; 50: 206-11.

7. Baer FJ, D‘Haens GR, Peeters M, et al. Tumor necrosis factor alpha antibody (infliximab) therapy profoundly down-regulates the inflammation in Crohn's ileocolitis. Gastroenterology 1999; 116: 22-8.

8. Rutgeerts PJ. Review article: Efficacy of infliximab in Crohn's disease-induction and maintenance of remission. Aliment Pharmacol Ther 1999; 13: 9-15.

9. Present DH. Review article: the efficacy of infliximab in Crohn's disease-healing of fistulae. Aliment Pharmacol Ther 1999; 13: 23-8.

10. Martínez-Borra J, López-Larrea C, González S, et al. High serum tumor necrosis factor-alpha levels are associated with lack of response to infliximab in fistulising Crohn's disease. Am J Gastroenterol 2002; 97: 2350-6.

11. Mascheretti S, Hampe J, Croucher PJ, et al. Response to infliximab treatment in Crohn's disease is not associated with mutations in the CARD15 (NOD2) gene: an analysis in 534 patients from two multicenter, prospective GCP-level trials. Pharmacogenetics 2002; 12: 509-15.

12. Vermeire S, Louis E, Rutgeers P, et al. NOD2/CARD15 does not influence response to infliximab in Crohn's disease. Gastroenterology 2002; 123: 106-11.

13. Esters N, Vermeire S, Joossens S, et al. Serological markers for prediction of response to anti-tumor necrosis factor treatment in Crohn's disease. Am J Gastroenterol 2002; 97: 1458-562.

14. Nikolaus S, Raedler A, Kuhbacker T, et al. Mechanisms in failure of infliximab for Crohn's disease. Lancet 2000; 356: 1475-9.

15. Lennard-Jones JE. Classification of inflammatory bowel disease. Scand J Gastroenterol Suppl 1989; 170: 2-6.

16. Targan SR, Hanauer SB, van Deventer SJ, et al. A short-term study of chimeric monoclonal antibody cA2 to tumor necrosis factor alpha for Crohn's disease. Crohn's disease cA2 Study Group. N Engl J Med 1997; 337: 1029-35.

17. Present DH, Rutgeerts $\mathrm{P}$, Targan $\mathrm{S}$, et al. Infliximab for the treatment of fistulas in patients with Crohn's disease. N Engl J Med 1999; 340: 1398-405.

18. Present DH, Korelitz BI, Wisch N, et al. Treatment of Crohn's disease with 6-mercaptopurine: a long-term, randomised, double-blind study. New Engl J Med 1980; 302: 981-7.

19. Pearson DC, May GR, Fick GH, et al. Azathioprine and 6-mercaptopurine in Crohn's disease: A meta-analysis. Ann Intern Med 1995; 123: 132-42.

20. Ricart E, Panaccione R, Loftus EV, et al. Infliximab for Crohn's disease in clinical practice at the Mayo Clinic: The first 100 patients. Am J Gastroenterol 2001; 96: 722-9. 
21. Farrell RJ, Shah SA, Lodhavia PJ, et al. Clinical experience with infliximab therapy in 100 patients with Crohn's disease. Am J Gastroenterol 2000; 95: 3490-7.

22. Ardizzone S, Colombo E, Maconi G, et al. Infliximab in treatment of Crohn's disease: the Milan experience. Dig Dis Sci 2002; 34: 411-8.

23. Cohen RD, Tsang JF, Hanauer SB. Infliximab in Crohn's disease: first anniversary clinical experience. Am J Gastroenterol 2000; 95: 3469-77.

24. Feffeman DS, Lodhavia PJ, Reinert S, et al. Smoking, age, duration of disease, gender, and other clinical factors do not predict response to infliximab in Crohn's disease. Gastroenterology 2001; 120 : A619.

25. Sample C, Bailey RJ, Todoruk D, et al. Clinical experience with infliximab for Crohn's disease: The first 100 patients in Edmonton, Alberta. Can J Gastroenterol 2002; 16: 165-70.

26. Vermeire S, Louis E, Carbonez A, et al. Demographic and clinical parameters influencing the short-term outcome of anti-tumor necrosis factor (infliximab) treatment in Crohn's disease. Am J Gastroenterol 2002; 97: 2357-63.

27. Parsi MA, Achkar JP, Richardson S, et al. Predictors of response to infliximab in patients with Crohn's disease. Gastroenterology 2002; 123: $707-13$
28. Ochsenkuhn T, Goke B, Sackmann M. Combining infliximab with 6mercaptopurine/azathioprine for fistula therapy in Crohn's disease. Am J Gastroenterol 2002; 97: 2022-5.

29. Rutgeerts P, D‘Haens G, Targan S, et al. Efficacy and safety of retreatment with anti-tumor necrosis factor antibody (infliximab) to maintain remission in Crohn's disease. Gastroenterology 1999; 117: 761-9.

30. Hanauer SB, Feagan BG, Lichtenstein GR, et al. Maintenance infliximab for Crohn's disease: the ACCENT I randomised trial. Lancet 2002; 359: 1541-9.

31. Hanauer SB. Review article: Safety of infliximab in clinical trials Aliment Pharmacol Ther 1999; 13: 16-22.

32. Kugathasan S, Levy MB, Saeian K, et al. Infliximab retreatment in adults and children with Crohn's disease: risk factors for the development of delayed severe systemic reaction. Am J Gastroenterol 2002; 97: 1408-14.

33. Keane J, Gershon S, Wise RP, et al. Tuberculosis associated with infliximab, a tumor necrosis factor a-neutralizing agent. New Engl J Med 2001; 345: 1098-103.

34. Sandborn WJ, Haunauer SB. Antitumor necrosis factor therapy for inflammatory bowel disease: a review of agents, pharmacology, clinical results, and safety. Imflamm Bowel Dis 1999; 5: 119-33.

35. Vermeire S, Norman M, Van Assche G, et al. Infliximab (Remicade) treatment in Crohn's disease and antinuclear antibody (ANA) formation. Gastroenterology 2001; 120: A69.

\title{
Retratamiento y tratamiento de mantenimiento con infliximab en la enfermedad de Crohn fistulizante
}

\author{
L. Rodrigo, J. M. Pérez-Pariente, D. Fuentes, V. Cadahia, A. García-Carbonero, P. Niño, R. de Francisco, R. Tojo, \\ M. Moreno y E. González-Ballina
}

Servicio de Aparato Digestivo. Hospital Central de Asturias. Oviedo

\section{RESUMEN}

Objetivos: el infliximab ha demostrado su eficacia en el tratamiento a corto plazo de la enfermedad de Crohn (EC) fistulosa. En este trabajo presentamos los resultados del retratamiento y del tratamiento de mantenimiento a largo plazo.

Pacientes y métodos: se trataron con infliximab un total de 81 pacientes consecutivos con EC fistulosa activa, en los cuales, habían fallado tratamientos previos. Todos los pacientes recibieron como tratamiento inicial infusiones a dosis de $5 \mathrm{mg} / \mathrm{kg}$ i.v. en las semanas 0,2 y 6 . Aquellos pacientes que no respondieron después del ciclo inicial (grupo 1, n=25), o los que recayeron después de haber respondido (grupo $2, n=13$ ), recibieron retratamiento con 3 dosis similares (semanas 0,2 y 6 ). Aquellos que respondieron a la terapia de retratamiento fueron incluidos en un programa de mantenimiento a largo plazo $(n=44)$, con dosis repetidas (infusiones con $5 \mathrm{mg} / \mathrm{kg}$ i.v.) cada 8 semanas, durante $1-2$ años.

Resultados: en el tratamiento inicial el 56\% de los pacientes respondieron parcialmente, siendo la respuesta completa del $44 \%$. En la modalidad del retratamiento, el $28 \%$ de los pacientes del grupo 1 (no respondedores) presentaron respuesta completa frente al $77 \%$ del grupo 2 (recidivantes) $(p<0,0001)$
En el grupo de tratamiento de mantenimiento, la respuesta global fue del $88 \%$. La media de dosis por paciente fue de 4,4 \pm 2 (rango 1-9) con una duración media del tratamiento de $36 \pm 12$ semanas (rango 8-72). Los efectos adversos no aumentaron significativamente en los grupos de retratamiento y mantenimiento, comparados con el tratamiento inicial.

Conclusiones: ambas modalidades de administración del infliximab, a saber el retratamiento y el tratamiento de mantenimiento a largo plazo, son muy efectivas y bien toleradas en pacientes con enfermedad de Crohn fistulosa.

Palabras clave: Retratamiento. Tratamiento de mantenimiento. Infliximab. Enfermedad de Crohn fistulizante.

\section{INTRODUCCIÓN}

La enfermedad de Crohn (EC) es una enfermedad inflamatoria intestinal de origen desconocido, caracterizada por la existencia de una inflamación transmural y discontinua de la pared del intestino delgado y/o del colon, pudiendo afec- 
tar además a cualquier parte del tubo digestivo, desde la boca hasta el ano.

Puede presentar varias complicaciones locales, incluyendo la presencia de rectorragia, obstrucción intestinal, perforación, así como la existencia de fístulas internas (entero-entéricas, entero-vesical, etc.) o externas (perianal, entero-cutáneas), etc.

Se emplean y se han venido utilizando diversos tratamientos médicos en el manejo de la enfermedad de Crohn, tales como corticoides orales o intravenosos, aminosalicilatos orales o tópicos, nutrición enteral y parenteral, antibióticos y los inmunosupresores solos o combinados con los anteriores, dependiendo de la localización de la enfermedad y del estado clínico del paciente.

Varios estudios muestran que la producción de TNF- $\alpha$ está incrementada, tanto en suero como en la mucosa intestinal, en pacientes con EC (1,2). El infliximab (Remicade $\left.{ }^{\circledR}\right)$ es un anticuerpo monoclonal quimérico humano-murino, capaz de unirse al TNF- $\alpha$, tanto libre como al fijado a nivel de las membranas celulares, bloqueando la interacción con sus receptores y neutralizando así su actividad biológica $(3,4)$. A través de estos mecanismos, se produce una apoptosis celular de los linfocitos de la mucosa y submucosa intestinal, originando como consecuencia una potente acción inmunomoduladora y ejerciendo por tanto, una importante respuesta antiinflamatoria local y sistémica (5-7).

Diversos estudios han demostrado la eficacia del infliximab en el tratamiento de la EC, tanto en sus manifestaciones inflamatorias locales, como extra-intestinales y en el cierre de las fístulas asociadas $(8,9)$.

Aunque su eficacia a corto plazo en la enfermedad fistulosa ha sido bien demostrada, a medio plazo (alrededor de 12 semanas) un número considerable de pacientes presentan recaídas. Varios investigadores han intentado encontrar factores relacionados con la variabilidad individual de la respuesta y su duración (10-14). Hasta hoy, no ha sido posible identificar predictores clínicamente útiles de respuesta al tratamiento con infliximab, en pacientes con EC.

El tratamiento de mantenimiento a largo plazo, ha sido hasta hace un cierto tiempo, un tema sometido a debate y en el que existía escasa experiencia, pero que gracias a estudios publicados recientemente como el ACCENT-I, ha quedado definitivamente aceptado por la comunidad internacional, puesto que mejora y consolida notablemente los resultados observados en el tratamiento agudo.

El objetivo principal del presente trabajo consiste en describir nuestra experiencia en el tratamiento de la EC fistulosa con infliximab a largo plazo, incluyendo el retratamiento y la terapia de mantenimiento.

\section{PACIENTES Y MÉTODOS}

Desde abril de 1999 hasta octubre de 2003, hemos tratado un total de 81 pacientes consecutivos con EC fistulosa con infliximab. El diagnóstico de EC fue confirmado mediante hallazgos clínicos, endoscópicos, radiológicos e histológicos, siguiendo los criterios de Lennard Jones (15).

Los pacientes fueron informados de la situación de su enfermedad y de las distintas posibilidades terapéuticas, y también se les proporcionó una información detallada acerca de las características del infliximab y de sus posibles efectos adversos, obteniéndose un consentimiento informado en todos los casos, antes de su administración. En la semana previa a la infusión intravenosa del infliximab, se realizó a todos los pacientes, una radiografía de tórax p-a y lateral, así como una prueba de la tuberculina al 1/10.000 y en los casos de positividad de esta, se realizó profilaxis con hidrazidas. El protocolo y el régimen de tratamiento fueron aprobados por el Comité Ético de nuestro hospital.

La indicación establecida para el tratamiento en todos los pacientes incluidos en nuestra serie, fue la presencia de EC fistulosa, con presencia de una o varias fístulas activas, al menos durante los 3 meses previos a la infusión del infliximab, tras el fracaso en la utilización de tratamientos previos (aminosalicilatos, antibióticos, inmunosupresores, setones, etc.).

Para la evaluación de la enfermedad fistulosa, se realizó una exploración física de la región perianal, una colonoscopia completa, una ecografía endoanal y una resonancia magnética de la pelvis, para valorar el número, trayecto, situación y estado de actividad de las fístulas.

El $90 \%$ por ciento de los pacientes estaban recibiendo tratamiento con dosis estándar de azatioprina $(2,5 \mathrm{mg} / \mathrm{kg} / \mathrm{día})$ durante $28 \pm 26$ meses, rango (6-120) .

El infliximab se administró mediante infusión intravenosa (i.v.) la dosis de $5 \mathrm{mg} / \mathrm{kg}$ durante 2,30 horas, siguiendo las instrucciones del laboratorio que lo suministra (Laboratorios Schering-Plough, USA), en 3 dosis separadas a los intervalos habituales (semanas 0,2 y 6). Con esta finalidad se empleó el Hospital de Día del Servicio de Digestivo, donde estaban ingresados toda la mañana.

Los pacientes permanecían durante 6 horas en observación. Todos los pacientes eran observados cada 30 minutos, para vigilar la posible aparición de efectos adversos, tanto durante la infusión i.v., como durante 3 horas después de su finalización. Posteriormente eran dados de alta y se realizaba un seguimiento telefónico cada 24 horas, durante 3 días.

Se registraron todos los acontecimientos clínicos ocurridos durante la infusión i.v., periodo de observación y durante la fase de seguimiento. Se realizaron revisiones periódicas en las semanas 2 y 4 después de la infusión y posteriormente cada 4 semanas, o cuando el paciente experimentaba cualquier complicación o cambio clínico en su enfermedad, o cuando acudían a nuestro Servicio.

Se llevó a cabo una valoración clínico-analítica completa, incluyendo determinación de reactantes de fase aguda en cada visita, y las alteraciones que pudieran aparecer en el curso de la enfermedad, tales como la aparición de posibles efectos secundarios, cambio en el número o actividad de las fístulas y /o desarrollo de otras complicaciones relacionadas con la enfermedad (abscesos, episodios suboclusivos), fueron registradas.

En los casos en que podían existir dudas acerca del cierre de las fístulas, la aparición de otras, o la posibilidad de desarrollar nuevas complicaciones de las mismas, se repitieron estudios de imagen (ecografía endoanal y/o RMN).

Para la interpretación de los resultados, se consideró como respuesta parcial, el cierre de al menos el $50 \%$ de las 
fístulas existentes al inicio del tratamiento y respuesta completa, el cierre de todas las fístulas, al final del ciclo de tratamiento (semana 6).

Desde febrero de 2000, se comenzó a retratar (repetir la administración con 3 nuevas dosis), en un intento de obtener respuesta en los pacientes que no habían respondido al tratamiento inicial (grupo 1, $\mathrm{n}=25$ ), y en aquellos que habiendo respondido inicialmente, presentaban posteriormente una recaída (grupo 2, $\mathrm{n}=13$ ). Once pacientes rehusaron el retratamiento por las siguientes razones: a) ausencia de eficacia $(n=6) ; y$ b) paso a cirugía $(n=5)$.

Desde marzo de 2001, se inició un programa de tratamiento de mantenimiento para consolidar la respuesta en aquellos pacientes que habían respondido (tanto después de un ciclo inicial, como después del retratamiento). La pauta de administración en todos los casos, fue de una dosis de $5 \mathrm{mg} / \mathrm{kg}$, cada 8 semanas. En esta modalidad de tratamiento se incluyeron un total de 44 pacientes, de los que 19 habían recibido retratamiento, y los 25 restantes fueron incluidos directamente a partir del tratamiento inicial (Fig. 1).

No administramos de forma rutinaria medicación con corticoesteroides y/o anti-histamínicos previa a la infusión i.v. de nuevas dosis de infliximab y solamente se administraban en caso de aparición de reacciones alérgicas de tipo cutáneo o respiratorio (urticaria o asma).

\section{Análisis estadístico}

Las variables cuantitativas se expresan como media y desviación estándar y las cualitativas como porcentajes. Para el análisis de los resultados obtenidos se utilizó el test de la t de Student para los datos cuantitativos y el test de la $\chi^{2}$ (Chi cuadrado) con la corrección exacta de Fisher, para datos cualitativos y porcentajes. Los datos que no siguieron una distribución homogénea fueron analizados usando pruebas no paramétricas (U de Mann-Whitney y Kruskal-Wa1lis). Para el análisis de los diferentes factores demográficos se realizó un análisis multivariable. Una $\mathrm{p}<0,05$ se consideró como estadísticamente significativa. Se utilizó el paquete SPSS versión 11.0 (SPSS. Illinois, USA) para el análisis de datos.

\section{RESULTADOS}

Los pacientes fueron agrupados según la clasificación de Viena. La localización de la mayoría de las fístulas fue perianal $(80 \%)$. Otras variables demográficas como el sexo y los hábitos tóxicos, duración de la enfermedad y número de fístulas fueron recogidas y se muestran en la tabla I.

\section{Resultados del tratamiento inicial}

Se consiguió respuesta en el 55,6\% de los pacientes $(45 / 81)$; esta se alcanzó en la semana $2,1 \pm 1$. La respuesta fue completa en el 44,4\% de los casos (36/81), alcanzada en la semana $2,5 \pm 1$.
Tabla I. Características basales de los pacientes $(n=81)$

\begin{tabular}{|c|c|}
\hline$\overline{\text { Edad, años (media } \pm \text { desv. típica, rango) }}$ & $36 \pm 14(18-72)$ \\
\hline Sexo (mujeres/ hombres) (n, relación) & $37 / 44(1 / 1,2)$ \\
\hline Duración de la enfermedad (años) (media, rango) & $7,6 \pm 7(1-25)$ \\
\hline Duración de las fístulas (años) (media, rango) & $2,3 \pm 2,4(1-10)$ \\
\hline \multicolumn{2}{|l|}{ Fumadores $(n, \%)$} \\
\hline Sí & $27(33 \%)$ \\
\hline No & $43(53 \%)$ \\
\hline Ex-fumadores & $11(14 \%)$ \\
\hline \multicolumn{2}{|l|}{ Localización de la enfermedad $(n, \%)$} \\
\hline Ileo-cecal (L1) & $24(30 \%)$ \\
\hline Colónica (L2) & $11(13 \%)$ \\
\hline Ileocólica (L3) & $46(57 \%)$ \\
\hline \multicolumn{2}{|l|}{ Azatioprina $(n, \%)$} \\
\hline Sí & $73(89 \%)$ \\
\hline No & $8(11 \%)$ \\
\hline \multicolumn{2}{|l|}{ Localización de las fístulas ( $n, \%)$} \\
\hline Perianales & $65(80 \%)$ \\
\hline Entero-cutáneas & $13(16 \%)$ \\
\hline Ambas & $3(4 \%)$ \\
\hline Número de fístulas (media \pm desv. típica, rango) & $2 \pm 1,2(1-6)$ \\
\hline
\end{tabular}

Ninguno de los 4 pacientes con fístulas entero-vesicales asociadas, y sólo 1 de los 4 pacientes con fístula entero-vaginal, presentó respuesta completa. Comparando las características de los pacientes respondedores con los no-respondedores, no se encontraron diferencias significativas.

La duración de la enfermedad se acercó a la significación $(\mathrm{p}=0,05)$; siendo mayor en los no respondedores $(9,6 \pm 7,6$ vs 6,3 \pm 6 años) (Tabla II).

\section{Retratamientos}

Grupo $1(\mathrm{n}=25)$ : se observó respuesta completa en el $28 \%(7 / 25)$ y ocurrió en la semana $2,4 \pm 1,2$. De estos pacientes, 3 correspondían a casos en los que la azatioprina fue administrada después del $1^{\text {er }}$ ciclo de infliximab. No se observaron diferencias estadísticamente significativas entre respondedores y no-respondedores. Los pacientes que presentaron respuesta completa, fueron incluidos posteriormente en programa de mantenimiento.

Grupo $2(n=13)$ : se alcanzó respuesta parcial en el 92,3\% de los casos (12/13) y respuesta completa en $77 \%(10 / 13)$. Los pacientes respondedores fueron igualmente incluidos en programa de mantenimiento.

Comparando el porcentaje de respuesta entre los grupos 1 y 2 , se observaron diferencias estadísticamente significativas $(\mathrm{p}<0,0001)$ (Fig. 2).

\section{Tratamiento de mantenimiento}

De los 44 pacientes tratados, sólo cinco, presentaron recidivas. El índice de respuesta inicial al tratamiento de mantenimiento fue del $88 \%$ (39/44) con un número medio de dosis de 4,4 \pm 2 por paciente (rango 1-9) (Fig. 3), que equivale a $36 \pm 12$ semanas (rango 8-72). La semana 0 en el tratamien- 
Tabla II. Respondedores frente a no-respondedores

\begin{tabular}{|c|c|c|c|}
\hline & $\begin{array}{c}\text { Respondedores } \\
(n=45)\end{array}$ & $\begin{array}{c}\text { No-respondedores } \\
\quad(n=36)\end{array}$ & $p$ \\
\hline Edad (años) (media \pm desv, típica, rango) & $36 \pm 14(16-72)$ & $38,3 \pm 14(18-64)$ & (ns) \\
\hline $\operatorname{Sexo}(n, \%)$ & & & (ns) \\
\hline Mujeres & $20(43 \%)$ & $17(47 \%)$ & \\
\hline Duración de la enfermedad en años (media, rango) & $6,3 \pm 6(1-25)$ & $9,6 \pm 7,6(1-20)$ & $(p=0,05)$ \\
\hline Duración de las fístulas en años (media, rango) & $1,4 \pm 1$ & $3,1 \pm 3$ & (ns) \\
\hline No & $19(42 \%)$ & $24(67 \%)$ & \\
\hline Ex-fumadores & $6(13, \%)$ & $5(14 \%)$ & \\
\hline Localización de la enfermedad (n,\%) & & & (ns) \\
\hline Íleo-cecal (L1) & $14(31 \%)$ & $10(28 \%)$ & \\
\hline Colónica (L2) & $5(11 \%)$ & $6(17 \%)$ & \\
\hline Ileocólica (L3) & $26(58 \%)$ & $20(55 \%)$ & \\
\hline
\end{tabular}

to de mantenimiento, fue considerada al comienzo de la administración de la primera dosis con dicha finalidad (Fig. 4).

\section{Efectos secundarios}

La media y el tipo de efectos adversos observados se muestran en la figura 5. Se observaron 3 casos de tuberculosis pulmonar. La radiografía de tórax y la tuberculina habían sido negativas previas al tratamiento, 2 casos aparecieron después del tratamiento inicial y 1 después del retratamiento; todos ellos curaron completamente tras el tratamiento quimioterápico. La infusión se suspendió en 2 pacientes; en uno, debido a un episodio de disnea y en otro, por presentar una reacción anafiláctica, que se controló con tratamiento médico estándar (antihistamínicos y corticoesteroides). Este caso tardío se trataba de un paciente que recibió un ciclo de retratamiento, pasados siete meses después del inicial.

En nuestra serie no observamos un incremento significativo de complicaciones habituales con la administración del retratamiento o el tratamiento de mantenimiento.

Durante el desarrollo de este último observamos la aparición de anticuerpos antinucleares (ANA) en 11 de 45 pacientes $(25 \%)$, ninguno de los cuales presentó reacciones "lupus-like".

\section{DISCUSIÓN}

El tratamiento con infliximab ha demostrado una notable eficacia clínica, en el manejo de pacientes con enfermedad de Crohn (EC), en su forma puramente inflamatoria, tanto en estudios controlados con placebo (16), como en la práctica diaria, desde su comercialización.

La eficacia del infliximab en el cierre de las fístulas en la enfermedad de Crohn ha sido también evaluada (17), y se ha mostrado claramente superior al resto de tratamientos en estudios controlados, incluyendo inmunosupresores $(18,19)$.
Analizando los resultados obtenidos con el primer ciclo de tratamiento, observamos una respuesta parcial del 55,6\% (45/81). Estos resultados son ligeramente inferiores que los comunicados por autores de la Clínica Mayo (20) (69\%) o los obtenidos por Farrel y cols. (21) (65\%) y similares a los descritos en otras series (22). El porcentaje de pacientes que presentó una respuesta completa $(44,4 \%)$ fue también similar a las series mencionadas anteriormente y superiores a los obtenidos por Cohen y cols. (23) (24\% en la semana 3 ) debido probablemente a que en esta serie, sólo un $38 \%$ de pacientes recibieron las tres dosis completas del tratamiento con infliximab.

Con respecto a las características clínicas y analíticas de los pacientes no se encontraron diferencias significativas en la mayoría de los factores analizados entre pacientes respondedores y no respondedores, como se ha puesto de manifiesto en otros estudios $(24,25)$. La duración de la enfermedad se aproxima a la significación, probablemente debido a un tamaño de muestra pequeño. En nuestra serie es ligeramente mayor en los no respondedores $(\mathrm{p}=0,05)$.

En una publicación reciente (26) una respuesta mayor ha sido descrita en pacientes jóvenes con afectación crónica y uso concomitante de inmunosupresores. Muchos estudios muestran un mayor porcentaje de respuesta en pacientes previamente tratados con azatioprina. Otros estudios, sin embargo, han observado un mayor índice de respuesta en pacientes no fumadores, aunque no encontraron diferencias en el porcentaje inicial de respuesta (27).

En la fase de retratamiento, observamos un menor porcentaje de respuesta en el grupo 1, constituido por pacientes no-respondedores al tratamiento inicial $(28 \%, 7 / 25)$ lo que apoyaría la idea de "dar una $2^{\mathrm{a}}$ oportunidad a estos pacientes", aunque es importante resaltar que 3 de los 7 pacientes que presentaron respuesta, corresponden a aquellos que no habían recibido tratamiento inmunosupresor durante el $1^{\mathrm{er}}$ ciclo y que dicho porcentaje podría haber sido mayor que el observado, si se hubiera empleado previamente tratamiento combinado con azatioprina. 
En el grupo 2, obtuvimos un mayor porcentaje de respuesta $(92,3 \%, 12 / 13)$ que fue significativamente mayor que el registrado en el grupo 1 . Por ello pensamos que el retratamiento de pacientes que han respondido al tratamiento con infliximab y que posteriormente han recidivado (normalmente ocurre en la mayoría de los casos, en los que sólo se realiza un ciclo inicial), tienen una alta posibilidad de nuevo cierre de las fístulas, con un $2^{\circ}$ ciclo. El tiempo medio de respuesta en pacientes con fístulas es de alrededor de 12 semanas, después del tratamiento inicial (28).

Estudios recientes demuestran la eficacia del tratamiento de mantenimiento, especialmente en el caso de enfermedad inflamatoria activa (29), como el ACCENT-1, que es un estudio multicéntrico con una serie amplia que comprende un total de 573 pacientes (30), cuyos resultados muestran que es altamente efectivo, seguro y bien tolerado. Otras series clínicas publicadas previamente, aportaron la posibilidad de que estos resultados puedan también obtenerse en la enfermedad de Crohn fistulosa.

En nuestro estudio confirmamos esta hipótesis, ya que la mayoría de los pacientes que presentaron una respuesta inicial, y que fueron incluidos en el programa de mantenimiento, presentaron un cierre prolongado de las fístulas (88\%).

Con respecto a la seguridad de la medicación, nuestros datos concuerdan con los obtenidos en ensayos clínicos controlados, series clínicas y revisiones (31). No observamos un incremento significativo en el tipo ni en el número de reacciones adversas tras la administración de dosis sucesivas del fármaco.

Un paciente presentó una reacción anafiláctica moderada, que fue controlada de forma satisfactoria con la medicación habitual. Esta paciente tenía 20 años y había recibido un ciclo previo con respuesta completa y recaída posterior, razón por la que se decidió incluir en otro ciclo 7 meses más tarde. Presentó la reacción alérgica después de la primera dosis del $2^{\circ}$ ciclo. A fin de descender este riesgo al mínimo, se recomienda en general reducir el intervalo entre los ciclos, ya que a medida que aumenta el tiempo transcurrido entre la administración de dosis sucesivas de infliximab, parece incrementarse el porcentaje de aparición de reacciones alérgicas relacionadas con su administración (32).

En relación con el desarrollo de infecciones, existe un número significativo de casos de tuberculosis descritos en la literatura en relación con la administración del infliximab (33), por lo que es necesario tener en cuenta la posible reac- tivación de la tuberculosis durante el tratamiento, especialmente en países con alta prevalencia de esta enfermedad. Suele aparecer como formas diseminadas y de predominio extra-pulmonar. No obstante, desde que se realiza una búsqueda sistemática de la infección antes del tratamiento y se realiza una quimioprofilaxis adecuada en los casos tuberculin-positivos, ha disminuido notablemente la aparición de nuevos casos.

Otra complicación infecciosa significativa en nuestra serie, fue la aparición de tres abscesos perianales y dos abdominales, probablemente relacionados con que estos pacientes presentaban fístulas activas. Desde que realizamos un drenaje sistemático de los posibles abscesos perianales antes de iniciar el tratamiento con infliximab y se pautan antibióticos en todos los casos en los que se considera necesario, han disminuido notablemente estas complicaciones locales.

Otros efectos adversos fueron la aparición de un episodio de neumonía comunitaria y una candidiasis esofágica, debido probablemente al empleo de medicación inmunosupresora concomitante (como muchos autores sugieren), pese a que otros estudios muestran una mayor frecuencia de infecciones cuando se administra el infliximab sólo (34).

No observamos ningún caso de tumores linfoproliferativos. Aunque similar a otros estudios (35), el porcentaje de pacientes que presentaron positivización de los ANA durante el tratamiento con dosis repetidas (en un $25 \%$ de los casos), no se acompañó con aparición de enfermedades del colágeno asociadas (lupus o lupus-like).

Finalmente, deseamos subrayar como conclusión principal del presente trabajo, la elevada eficacia y seguridad conseguidas a medio y largo plazo con el retratamiento y la terapia de mantenimiento con infliximab en la enfermedad de Crohn complicada, alcanzando un excelente resultado en el cierre permanente de las fístulas y es lógico y deseable esperar obtener más resultados, con series más amplias y seguimientos más prolongados, para poder alcanzar conclusiones más definitivas.

\section{AGRADECIMIENTOS}

Queremos dar las gracias a David H. Wallace (Miembro de la Asociación Europea de Editores Científicos) por la traducción al inglés de este artículo. 